\title{
A Review: Ionic Conductivity of Solid Polymer Electrolyte Based Polyethylene Oxide
}

\author{
Siti Nurul 'Afini Mohd Johari', Nazrizawati Ahmad Tajuddin', \\ Hussein Hanibah ${ }^{2}$ \& Siti Khatijah Deraman ${ }^{2}$ \\ ${ }^{1}$ School of Chemistry and environment, Faculty of Applied Sciences, Universiti Teknologi MARA \\ (UiTM), 40450 Shah Alam, Selangor, Malaysia \\ ${ }^{2}$ Centre of Foundation Studies, Universiti Teknologi MARA, Cawangan Selangor, \\ Kampus Dengkil 43800 Dengkil, Selangor, Malaysia \\ *E-mail: drsitikhatijah@uitm.edu.my
}

Received: 4 July 2021 / Accepted: 20 August 2021 / Published: 10 September 2021

\begin{abstract}
Solid state electrolyte system-based polyethylene oxide (PEO) been widely used as one of the promising polymer host that mainly used in advance material such as secondary battery. They have many benefits of PEO such as good electrochemical stability, excellent compatibility with inorganic salts, reasonable fabrication cost, good safety, and good energy density. However, due to the semicrystalline behaviour this electrolyte system poor mechanical strength and thermo-stability limit its application in solid polymer electrolyte (SPE). Worldwide research has been conducted to enhance the mechanical strength and electrochemical properties of the PEO electrolyte system such as blending, inorganic filler and plasticizer etc. Therefore, in this review the topic has been narrow down on issues of PEO polymer electrolytes system.
\end{abstract}

Keywords: Polyethylene oxide, solid polymer electrolyte, ionic conductivity, inorganic filler, secondary battery

\section{$\underline{\text { FULL TEXT }}$}

(C) 2021 The Authors. Published by ESG (www.electrochemsci.org). This article is an open access article distributed under the terms and conditions of the Creative Commons Attribution license (http://creativecommons.org/licenses/by/4.0/). 